University of Nebraska - Lincoln

DigitalCommons@University of Nebraska - Lincoln

Library Philosophy and Practice (e-journal)

Libraries at University of Nebraska-Lincoln

$6-2021$

\title{
Measuring the Global Research Output and Visualization on Gender Equality: A Bibliometric Analysis
}

Navaneeta Majumder

GLS Law College, Ahmedabad, majumdernavaneeta@gmail.com

Mayuri Pandya

GLS Law College, Ahmedabad, mayurihimanshu@gmail.com

Shanti P. Chaudhari

Pandit Deendayal Energy University, Gandhinagar, shanti.chaudhari@gmail.com

Atul Bhatt

Gujarat University Ahmedabad, dratulbhatt@gmail.com

Dharmendra Trivedi

L\&T Institute of Project Management, Vadodara, 1974dtrivedi@gmail.com

Follow this and additional works at: https://digitalcommons.unl.edu/libphilprac

Part of the Library and Information Science Commons

Majumder, Navaneeta; Pandya, Mayuri; Chaudhari, Shanti P.; Bhatt, Atul; and Trivedi, Dharmendra, "Measuring the Global Research Output and Visualization on Gender Equality: A Bibliometric Analysis" (2021). Library Philosophy and Practice (e-journal). 5803.

https://digitalcommons.unl.edu/libphilprac/5803 


\section{Measuring the Global Research Output and Visualization on Gender Equality: A Bibliometric Analysis}

\author{
Navaneeta Majumder \\ Assistant Professor \\ GLS Law College, Ahmedabad, India \\ Email:majumdernavaneeta@gmail.com
}

\author{
Shanti P. Chaudhari \\ Pandit Deendayal Energy University \\ Gandhinagar, India \\ Email: shanti.chaudhari@gmail.com
}

\author{
Mayuri Pandya \\ Director \\ GLS Law College, Ahmedabad, India \\ Email: mayurihimanshu@gmail.com
}

\author{
Atul Bhatt \\ Associate Professor \\ Dept. of LIS, Gujarat University, \\ Ahmedabad, India \\ Email:dratulbhatt@gmail.com
}

\section{Dharmendra Trivedi* \\ Librarian, L\&T Institute of Project Management \\ L\&T Knowledge city, Vadodara, India \\ Email: 1974dtrivedi@gmail.com}

\section{Abstract:}

The purpose of present study is to explore the bibliometric features of scientific productions in the domain of gender studies for the period of 2011-2020. The data of the scientific productions were retrieved from the Scopus database. The key words "Gender" and "Equality" were applied as topic terms to search articles published during the study period. The statistical analysis was conducted by using the R Studio, MS Excel and VOS Viewer. A total of 7619 scientific productions were published during the study period. It was found that in the last decade there is a $238 \%$ increase in the number of publications on gender equality. Majority of the papers (73.87\%) were published as journal articles. USA and UK are leading in terms of distribution of country wise research productions. Together they account for nearly half (48\%) of the publications. Geary DC (USA) and Stoet (UK) are the most cited authors and the journal 'Gender and Development' has the highest numbers of publications. Many bibliometric studies have been conducted in the domain of natural and life sciences, but very few studies have been conducted in the field of social sciences. Therefore, the researchers can gain from the bibliometric information regarding the scientific productions in the field of gender equality, which is one of the dominant fields of inquiry of social sciences. The present study will provide important information regarding the trends of academic publication in the field of gender equality. It is the first systematic study on gender equality which assist the researchers to comprehend the most prominent contributions, productive journals, prolific authors, country specific productivity and other related indicators.

Keywords: Gender Equality, Bibliometrics, Citation Analysis, Scientometrics; VOSViewer; Social Sc. 


\section{Introduction}

Gender as a term describes socially constructed roles and responsibilities, which different societies consider appropriate for their men and women, (Peace Corps, 2021) whereas sex is a biologically defined term. As a result, people are born as male and female (biological traits) and subsequently, they learn to be boys and girls, who grow-up in to men and women. Thus, this socially learned behaviour, develops one's gender identity and determines gender roles. (Torgrimson \& Minson, 2005) Accordingly, World Health Organization (WHO) has explained 'gender equality' as a scenario, where there is no discrimination on the basis of one's sexual traits, especially in terms of opportunities, allocation and access to resources, benefits and services available in the society. (WHO, 2002)

In recent years, the World Economic Forum has published the Global Gender Report 2017, which highlighted that though women constitute half of world's population, they lack equal access to healthcare and educational institutions, economic and potential earning opportunities and power to make political decisions. (Miotto, Lopez, \& Rodriguez, 2019) Internationally, the "Economic Participation and Opportunity Gap" is nearly 58 per cent, signifying the huge differences which gender still constitute in the potential achievement of happiness and wealth. (Schwab, et al., 2017)

To bridge the potential gender gap, gender equality has become important to accomplish the agenda of Sustainable Development Goals (SDGs), where the targets and indicators on gender equality will work as strong incentive for action. The SDGs through its 'Goal - 5' envisages that women should enjoy equal rights and opportunities, while being able to live a life, which is free from any form of violence and discrimination. (UN Women, 2017) This is backed by the fact, that, gender equality is pertinent in its own way and also as a requirement for growth of economy, as well as, health and development of individuals and society. (OECD, 2015)

In the above light, gender equality is not only a fundamental right but it also acts as the basic foundation for a sustainable world. (UN, 2015) It also has immense relevance for reducing poverty and accelerating sustained economic growth of a society. Various studies have shown that gender-based inequalities acts as a hindrance in terms of both economic development and lowering of poverty. (OECD, 2010)

According to United Nations Office of The High Commission of Human Rights (OHCHR), though gender equality is a fundamental right, women on a regular basis suffer violation of their basic human rights, across their life cycle. This is because most societies fail to prioritise their attention to safeguard the human rights of women, thus, denying gender equality. (OHCHR, 2021) Gender equality also encompasses the agenda of social justice, which is mostly based on customary practices of a society. And most often such practices are detrimental to women. Therefore, in order to ensure human rights of half of the population, every country should ensure that all gender (men, women and transgender) shall enjoy equal opportunities in all sphere of life, such as, education, health, employment, wealth creation, 
etc. (Patel V. , 2014) In this light, it is very important for global social scientists and national, international and transnational organizations to understand the significance of the topic, while ensuring gender equality in all spheres of life.

The term bibliometrics has roots in the Latin and Greek words 'biblio' and 'metrics', signifying the application of mathematics, while studying bibliography. (Kolle, 2017) Bibliometrics is also known as scientometrics, which quantitatively evaluate the scientific articles and other published works, in terms of the authors of the published work, the journals - where the work has been published and the frequency of the citations of such articles. Here one's publications are increasingly evaluated from the statistics of their citations. (Jones, 2016) The aim of current study is to conduct an advanced search of the term 'Gender equality' in the network database platform of Scopus and to analyse the quantitative and qualitative features of the publications. The information generated may have the strength of providing insights into the potential of research on gender equality and also might provide guidance to the direction of future research on gender equality.

\section{Review of Literature}

Since last two decades the United Nations has promoted the concept of gender mainstreaming for creating a platform of gender equality, through its celebrated Beijing Platform for Action. The platform has maintained that gender equality refers to "equal rights, responsibilities and opportunities of women and men and girls and boys". (UN Women, 2021) According to a study by Palmieri, this has acted as a clarion call for developing objectives of various organizations working on the issue of gender equality and gender rights globally. (Palmieri, 2013)

A study by Barnett, has attempted to understand the concept of gender equality from the lens of women. It has found that most of the time, the way women assess gender equality is not same as the global indicators of gender inequality. The study highlights the issues of, who is defining the term gender equality? (Barnett, 2018) It has been found, that, most of the social scientist are not on the same page, when it comes to this question. As per Kurzman, the universalist looks at gender equality by applying same indicators on all societies, whereas, the subjectivist, contrarily sheds light on priorities of women and their life experiences, even though, certain women's perspective may look like biased and partial. (Kurzman, et al., 2019)

One particular study by Steel and Kabashima, reflects, that there are nations in East Asia, who are as rich as their western counterparts but they have a more gender biased society as compared to advanced western countries. (Steel \& Kabashima, 2008) Kurzman has emphasised that, such approaches are generally used in various cross-national surveys working in the field of gender studies. (Kurzman, et al., 2019) At the same time, the study by Barnett have shown, that, most of the national and international organizations have acknowledged that there is a need to consider the issue of gender equality, while 
taking any policy decisions. This acknowledgment reflects that the policymakers has started considering gender equality as norms, instead of just practice and thus, the organizations are also increasingly inclined to realise the impacts of these norms. (Barnett, 2018)

A study by Chary, have indicated that women are not adequately represented at the highest decisionmaking body, which reflects that though organizations are inclined to imbibe gender norms in their work culture, but they are losing out on a whole gamut of feminine way of thinking, working and decision-making. This according to Chary, is happening, because, today most of the organizations (nationally and internationally) are not only dominated by men but they are also designed by men to suit their working needs. Therefore, in such a scenario, the term gender equality may be inappropriate, because for women to compete and succeed in the outside world, they need to work and think like men. This reflect that in order to create space for women to grow, there is a need to bring in drastic changes in the way our social system functions, right from micro to macro level institutions. (Chary, 2016)

As part of literature review of a bibliometric study, it is also important to examine certain relevant literatures regarding both bibliometric studies and bibliometric literatures in the field of gender studies. A study by Chaudhari et. al. has highlighted that, in the contemporary times, bibliometric has emerged as an important scientific tool, which provides direction to develop policy and research documents. It further stated that bibliometric indicators are extensively used as a tool to conduct analysis of research performance. (Chaudhari, Bhatt, \& Mandalia, 2020) Another study by Patel and Bhatt, has also found that, bibliometric is used as effective tool to analyse the productivity performance of authors, journals, etc by using the process of both quantitative and qualitative evaluation of scientific publications. (Patel $\&$ Bhatt, 2019). As bibliometric study is very vital discipline of research and many research studies has been carry out in different areas like nursing discipline (Singh \& Pandita, 2018), area on ecology (Saravanan \& Dominik, 2014) etc.

In regard to bibliometric literature in the domain of gender equality, Kataria et. al. conducted a bibliometric study on the documents (retrieved from the Scopus database) published by a very reputed gender-based journal - Gender, Work and Organization. The study documented the evidences of various research publications of the esteemed journal during the time period of 1994-2018. The study mapped the publication and citation trend, indicating towards a trend of co-authorship. It also outlined the most outstanding topics, articles and authors, along with the development of collaborative network in the domain of gender studies. (Kataria, Kumar, \& Pandey, 2020)

Slavinski, et. al. conducted a bibliometric analysis of the features of published articles to analyse the dynamics of women, entrepreneurship and education. The study was conducted on a pool of articles published between the time frame of 1976 to 2020, which were retrieved from Scopus indexed journals. The study found that the retrieved papers were cited by nearly 5000 other Scopus indexed documents, highlighting the scholarly impact of the studies. Thus, this study may be conceptualised as a systematic 
study of scientific papers on specific gender issues published in journals of repute. (Slavinski, Todorovic, Vukmirovic, \& Montenegro, 2020)

Palomo, et. al. in their study has undertaken a bibliometric analysis with gender lens to track the development trajectory of publications of scientific papers on the theme of women, peace and security. For this purpose, the authors had retrieved Scopus indexed articles, within a time frame of 95 years, i.e., from 1918 to 2013. The data highlighted that there is presence of high rate of dispersion, in regards to the authors and the journals studied and at the same time, the study also attested a meagre amount of collaborative work between the Institutions and the authors. (Palomo, Domecq, \& Laguna, 2017)

\section{Objectives of the Study}

The primary objective of this study was to analyse the global research output on Gender Equality. To evaluate the research conducted in the domain of Gender Equality, year-wise growth of publication, authorship patterns, keywords used by various authors and citation received on published research will be assessed. Thus, in this regard, the following objectives were considered:

1 To study the year-wise growth of global research publication; type of research publications and country-wise research trends with most cited counties in Gender Equality

2 To identify most prolific authors and authors productive life in Gender Equality research

3 To examine most productive source titles and widely used keywords in Gender Equality research

4 To assess international collaborations in research output and top productive institutions of the world in Gender Equality research

\section{Data Collection and Methodology}

The data pertaining to the study on Gender Equality has been retrieved from the Scopus database in the fourth week of March 2021. A total of 7619 global publications in the field of Gender Equality during 2011 to 2020 were retrieved with keywords using 'Gender' and 'Equality', along with title and topic. Apart from this, various other search strategies were also developed to retrieve and analyse data from Scopus database. Subsequently, the data has been analysed by using statistical analysis software $\mathrm{R}$ Studio for tabular data format. The graphical representation was developed by using VOSViewer( software and MS Excel (Aria, M. \& Cuccurullo, C., 2017; RStudio Team, 2020; Vosviewer. (n.d.). In recent trends research in bibliometric analysis using VOSViewer has been increased rapidly in various domain and discipline of the research. (Haq et al., 2021; Das, 2021; Victoria, 2021; Laila et al., 2021) 


\section{Results and Analysis}

Bibliometric analysis was undertaken as a systematic method to determine the research trends in Gender Equality based on the results of the scientific database. The information received through this method helped to assess the contribution of a research domain, such as, gender equality, from various countries, categories, Institutions, journals and researchers. (Patyal, Jaspal, \& Khare, 2020)

\subsection{Growth of Global Research Publications, Total Citations and Average Citation}

Data obtained revealed that the annual scientific production/publications related to gender equality had increased steadily in the last decade. figure I, revealed the growth trend in scientific publications in terms of total publications, total citation and average citation per publication in the domain of gender equality from 2011-2020. The figure shows that the number of publications on gender equality has increased from 407 in 2011 to 1377 in 2020 . This indicates that in the last decade there was a $238 \%$ increase in the number of publications. At the same time, the cumulative number of scientific productions also has increased from 2524 papers during 2011 - 2015 to 5095 papers during 2016 2020 , a percentage rise of $102 \%$. This increasing trend of publications reflects a huge growth of global research in the field of gender equality, with an increasing momentum in the second half of the last decade.

Figure I

Total Publications (TP), Average citation per publication (ACPP) \& Total Citation (TC)

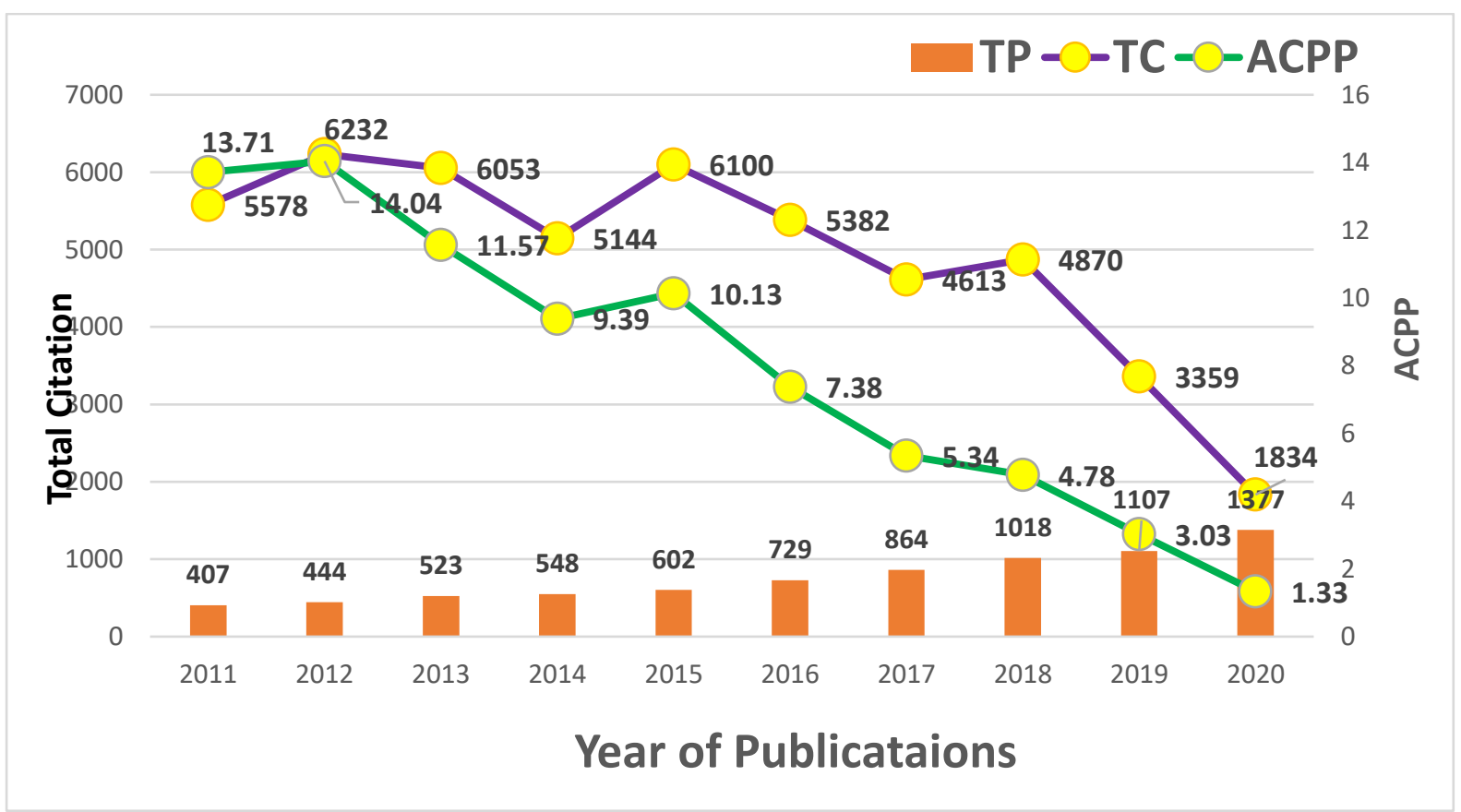


Table I shows the distribution of type of publications in the domain of Gender Equality. The Table indicates that in the period of 2011 - 2020, a total of 7619 articles were published in the field of Gender Equality. Majority of the papers $(5628,73.87 \%)$ were published as journal articles, followed by publication as book chapters $(972,12.76 \%)$, review article $(498,06.54 \%)$, conference paper/review $(275,03.61 \%)$, editorial/note/letter $(219,02.26 \%)$, short survey/data paper $(20,00.26 \%)$ and undefined $(7,00.09 \%)$. This reflects that globally, the scholars working in the domain of gender equality has a distinct preference for publication of their scientific works in journals. This may be because journals have a wider share of scholarly audience and a larger circulation.

\section{Table I}

Distribution of type of Publications

\begin{tabular}{lll}
\hline Type of Publication & $\begin{array}{l}\text { Number of } \\
\text { Publications }\end{array}$ & \% Share \\
\hline Journal Articles & 5628 & 73.87 \\
\hline Book Chapter & 972 & 12.76 \\
\hline Review Article & 498 & 06.54 \\
\hline Conference Paper/ Review & 275 & 03.61 \\
\hline Editorial/Note/Letter & 219 & 02.87 \\
\hline Short Survey/Data paper & 20 & 00.26 \\
\hline Undefined & 7 & 00.09 \\
\hline Total & $\mathbf{7 6 1 9}$ & $\mathbf{1 0 0}$
\end{tabular}

Note: It has been observed that there were 7620 articles, out of which 1 article has been retracted, and hence not published. Thus, that article has not been considered for the purpose of analysis.

\subsection{Distribution of Country-wise Scientific Research Production}

Figure II indicates distribution of country-wise scientific research production in the field of Gender Equality. The map was developed with the aid of R Studio and bing tool. As illustrated the leading territorial entities in terms of scientific productions are United States of America (2533), United Kingdom (1364), Spain (819), Sweden (774), Australia (609), Canada (544), Germany (465), Norway (328), Netherlands (327) and Italy (323). The data reflects, that, certain countries, such as, USA and UK have a hegemony in the domain of scientific productions in the field of gender equality. Together these two countries accounted for $48 \%$ (nearly half) of the total scientific productions. At the same time, the number of productions by the remaining ten countries ranged between 323 to 819 . Further analysis, reflects that, among the top ten countries, seven countries (UK, Spain, Sweden, Germany, Norway, Netherlands and Italy) are located in Europe, two (USA and Canada) in North America, and one 1 (Australia) in Oceania. This signifies, that regionally, the Europe is leading in terms of most numbers of Scientific Research Production. 


\section{Figure II}

\section{Visualization of Country-wise Scientific Research Productions}

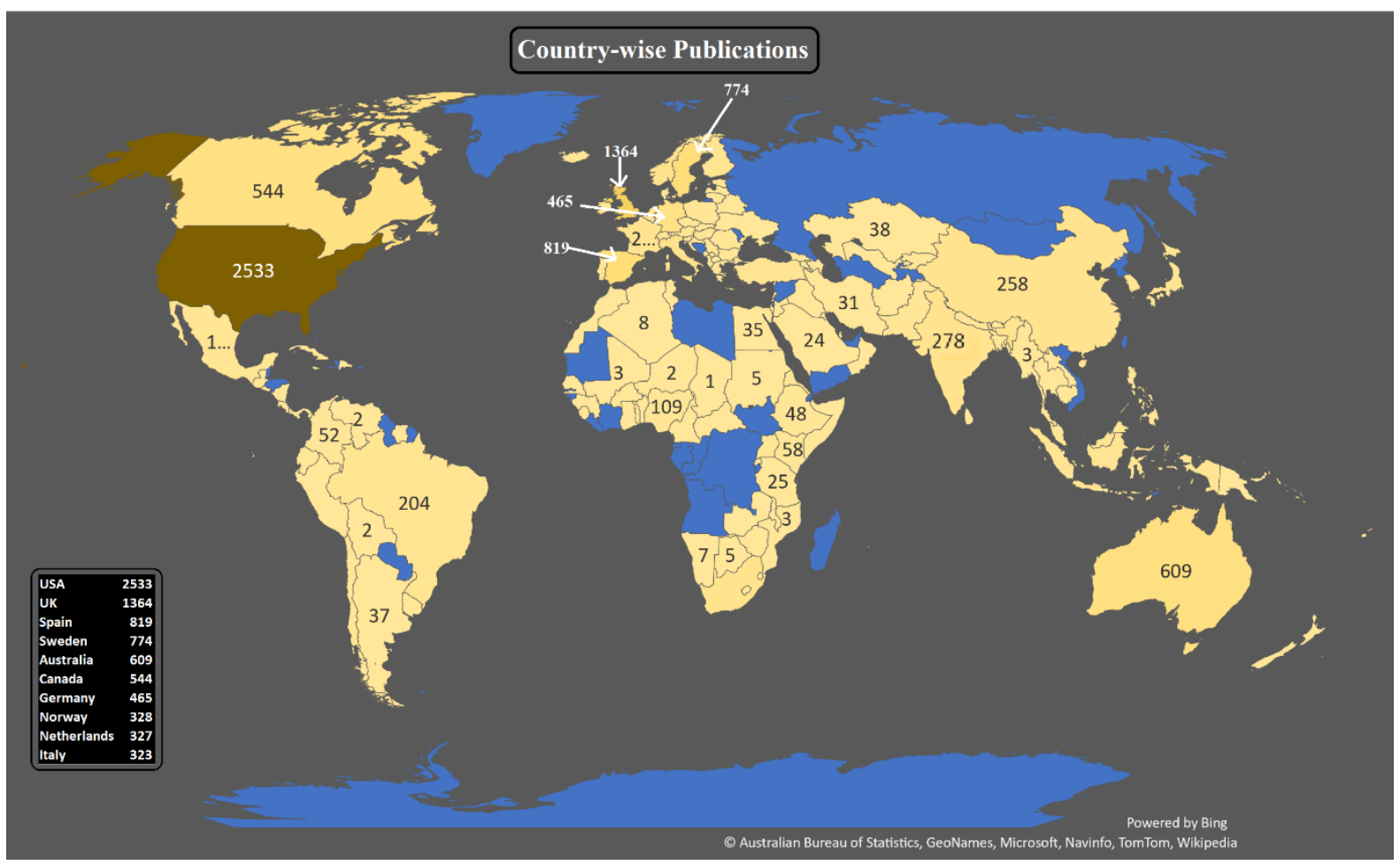

\subsection{Distribution of Country-wise Country-wise Citation Analysis}

Table II shows the list of most cited countries, along with the total citations received and average article citations during the period of 2011-2020 in the domain of gender equality. As shown in the Table II, the most cited countries, based on total number of citations are United States of America (9950, $11.93 \%$ ), followed by United Kingdom (5140, 9.716\%), Sweden (2871, 9.085\%), Spain (1926, 9.352\%), Australia (2179, 7.523\%) Canada (1836, 9.044), Netherlands (1206, 10.397\%), Germany $(1149,6.455 \%)$, Norway $(949,6.978 \%)$ and South Africa $(6.124 \%)$. The data reflects, that, in terms of citations too, USA and UK are dominating. Together these two countries accounted for more than half (54\%) of the total citations. At the same time, the number of total citations ranged by the remaining eight countries ranged between 2871 to 714 . It can also be seen that among the top 10 countries, six countries (UK, Sweden, Spain, Netherlands, Germany and Norway) are located in Europe, two (USA and Canada) in North America, one (South Africa) in Africa and one 1 (Australia) in Oceania. This highlight, that the European countries are leading in terms of most numbers of citations. 


\section{Table II}

\section{Distribution of Most Cited Countries}

\begin{tabular}{cccc}
\hline Country & TP & TC & ACPP \\
\hline USA & 2533 & 9950 & 3.93 \\
\hline UK & 1364 & 5140 & 3.77 \\
\hline Sweden & 819 & 2871 & 3.51 \\
\hline Spain & 774 & 1926 & 2.49 \\
\hline Australia & 609 & 2179 & 3.58 \\
\hline Canada & 544 & 1836 & 3.38 \\
\hline Netherlands & 465 & 1206 & 2.59 \\
\hline Germany & 328 & 1149 & 3.50 \\
\hline Norway & 327 & 949 & 2.90 \\
\hline South Africa & 323 & 741 & 2.29
\end{tabular}

TP: Total Publications; TC: Total Citation ; ACPP: Average Citation Per Publications

\subsection{Distribution of Most Prolific Authors}

Table III indicates the analysis of the top 10 most prolific authors, who have contributed in the domain of gender equality during 2011-2020. It will help to identify the influence of certain prolific authors in the study area. The ranking has been done on the basis of the number of times a particular author's article was cited, as this will aid to highlight their influence in the research area of gender studies. The Table shows, that, Geary DC (University of Missouri, USA) and Stoet (University of Essex, UK) have been ranked $1^{\text {st }}$, as during the period of study, they have contributed 5 articles each, with highest total citations of 487 and with h index 4 . Krook ML (Rutgers University, USA) is in the $3^{\text {rd }}$ position, with a contribution of 5 articles, 466 citations and h index 5. Connell R. (The University of Sydney, Australia) is in the $4^{\text {th }}$ position, with 3 articles, 376 citations and $\mathrm{h}$ index 3 . The $5^{\text {th }}$ position is accorded to Dworkin SL (University of Washington Bothell, USA) with a contribution of 6 articles, 366 citations and $\mathrm{h}$ index 5. True $\mathbf{J}$ (Monash University, Australia) is at $6^{\text {th }}$ position, who have contributed 6 articles, have 356 citations and the $\mathrm{h}$ index is 4 . Rudman LA Rutgers University - New Brunswick, USA) is at the $7^{\text {th }}$ position, with a contribution of 11 articles, 344 citations and $\mathrm{h}$ index 7 . The $8^{\text {th }}$ position has been occupied by Meinzen-Dick R and Quisumbing A from International Food Policy Research Institute, USA. Each has contributed 3 articles, have 330 citations and $\mathrm{h}$ index 3 . The $10^{\text {th }}$ position has been accorded to Duvander AZ (Stockholm Universiteit, Sweden), with a contribution of 20 articles, 308 citations and h index 8. 
Table III

Distribution of Most Prolific Authors

\begin{tabular}{|c|c|c|c|c|c|c|c|}
\hline Rank & $\begin{array}{l}\text { Author } \\
\text { Name }\end{array}$ & TP & $\mathbf{T C}$ & ACPP & h_index & Institution & Country \\
\hline 01 & Geary DC & 5 & 487 & 97.40 & 4 & University of Missouri, & USA \\
\hline 01 & Stpet G & 5 & 487 & 97.40 & 4 & University of Essex, & $\begin{array}{c}\text { United } \\
\text { Kingdom }\end{array}$ \\
\hline 02 & Krook ML & 5 & 466 & 93.20 & 5 & Rutgers University & USA \\
\hline 03 & Connell R & 3 & 376 & 125.33 & 3 & The University of Sydney & Australia \\
\hline 04 & Dworkin SL & 6 & 366 & 61.00 & 5 & $\begin{array}{c}\text { University of Washington- } \\
\text { Bothell } \\
\end{array}$ & USA \\
\hline 05 & True $\mathrm{J}$ & 6 & 356 & 59.33 & 4 & Monash University & Australia \\
\hline 06 & Rudman LA & 11 & 344 & 31.27 & 7 & $\begin{array}{c}\text { Rutgers University-New } \\
\text { Brunswick }\end{array}$ & USA \\
\hline 07 & $\begin{array}{c}\text { Meinzen-dick } \\
\text { R } \\
\end{array}$ & 3 & 330 & 110.00 & 3 & $\begin{array}{c}\text { International Food Policy } \\
\text { Research Institute }\end{array}$ & USA \\
\hline 07 & $\begin{array}{c}\text { Quisumbing } \\
\text { A } \\
\end{array}$ & 3 & 330 & 110.00 & 3 & $\begin{array}{c}\text { International Food Policy } \\
\text { Research Institute }\end{array}$ & USA \\
\hline 08 & Duvander AZ & 20 & 308 & 15.40 & 8 & Stockholm Universiteit & Sweden \\
\hline
\end{tabular}

\subsection{Distribution of Authors' Productive Life}

The Figure III, represents an authors' productive life in the research domain of gender equality during the study period of 2011-2020. It can be seen that Lombardo E and Hman A has consistently published papers in the domain of gender equality during the study period. Whereas, the shortest productive life was of Darmstadt GL, whose scientific contribution in the study area is for period of four years, i.e., from 2016-2020.

Figure III

Visualization of Top Authors' Production Over the Time Top-Authors' Production over the Time

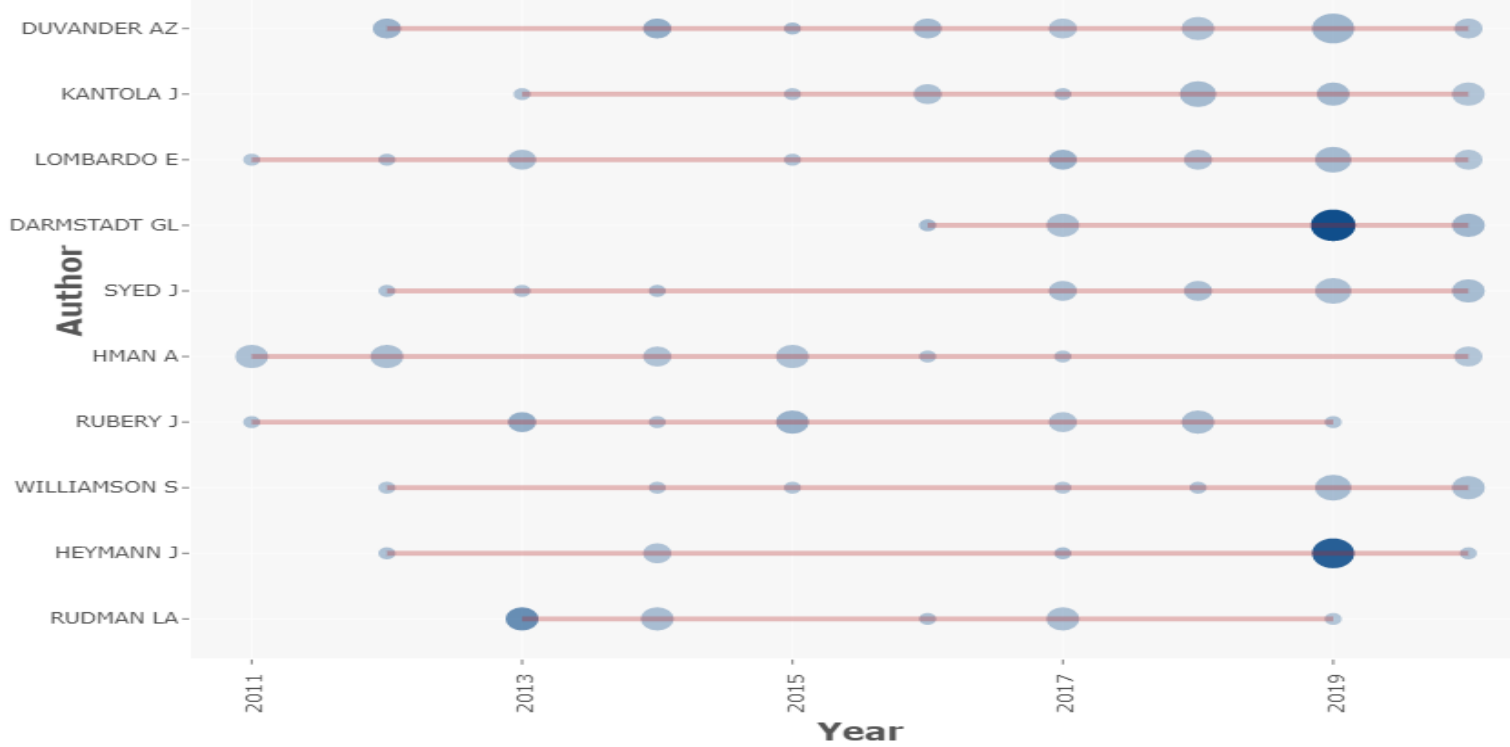




\subsection{Distribution of Most Productive Journals}

Table IV revealed the names of the top 10 productive journals, with their Scimago rankings in the field of gender equality during 2011-2020. The ranking has been done on the basis of the number of scientific productions (published articles) on gender equality during the said period. According to the Table, the journal named 'Gender and Development' has been ranked $1^{\text {st }}$, with the highest scientific production of 79 articles and a Scimago rank of 0.52 . The $2^{\text {nd }}$ position has been occupied by the journal 'Gender, Work and Organization', with publication of 72 articles and Scimago rank of 1.4. The journal titled 'Women's Studies International Forum' is in the $3^{\text {rd }}$ position, with 52 publication and Scimago rank of 0.43 . The $4^{\text {th }}$ position has been occupied by the journal named 'Sex Roles' with a scientific production of 57 articles and Scimago rank of 1.26. The journal of 'Sustainability Switzerland' is in the $5^{\text {th }}$ position with 55 published articles and Scimago rank of 0.58. The 'Journal of International Women's Studies' has been ranked $6^{\text {th }}$, with scientific production of 49 articles and Scimago rank of 0.21 . The journal 'Plos One' has been ranked $7^{\text {th }}$, which has published 47 articles and has a Scimago rank of 1.02 . The $8^{\text {th }}$ position has been accorded to the journal 'Gender and Education', with 41 publications and Scimago rank of 0.87 . The journal of 'Men and Masculinities' is at the $9^{\text {th }}$ position with 41 publications and Scimago rank of 0.79 . And the $10^{\text {th }}$ position has been occupied by the journal 'Equality, Diversity and Inclusion', with scientific production of 39 articles and Scimago rank of 0.37.

\section{Table IV}

\section{Distribution of Most Productive Journals}

\begin{tabular}{ccccccc}
\hline Journal Title & TP & TC & ACPP & $\begin{array}{c}\text { H_index } \\
\text { Journal }\end{array}$ & $\begin{array}{c}\text { Scimago } \\
\text { Journal } \\
\text { Rank }\end{array}$ & Publisher \\
\hline Gender and Development & 79 & 816 & 10.33 & 40 & 0.52 & Taylor \& Francis \\
\hline Gender Work and Organization & 72 & 934 & 12.97 & 73 & 1.4 & Wiley-Blackwell \\
\hline $\begin{array}{c}\text { Women's Studies International } \\
\text { Forum }\end{array}$ & 58 & 410 & 7.07 & 59 & 0.43 & Elsevier \\
\hline Sex Roles & 57 & 798 & 14.00 & 118 & 1.26 & Springer Nature \\
\hline $\begin{array}{c}\text { Sustainability Switzerland } \\
\text { Journal of International } \\
\text { Women's Studies }\end{array}$ & 55 & 533 & 9.69 & 85 & 0.58 & $\begin{array}{c}\text { Digital Publishing } \\
\text { Institute }\end{array}$ \\
\hline Plos One & 49 & 110 & 2.24 & 21 & 0.21 & $\begin{array}{c}\text { Bridgewater State } \\
\text { College }\end{array}$ \\
\hline Gender and Education & 41 & 764 & 16.26 & 332 & 1.02 & $\begin{array}{c}\text { Public Library of } \\
\text { Science }\end{array}$ \\
\hline Men and Masculinities & 41 & 548 & 13.37 & 59 & 0.79 & Taylor \& Francis \\
\hline $\begin{array}{c}\text { Equality Diversity and } \\
\text { Inclusion }\end{array}$ & 39 & 848 & 21.74 & 26 & 0.37 & $\begin{array}{c}\text { National Research } \\
\text { University Higher } \\
\text { School of } \\
\text { Economics }\end{array}$ \\
\hline
\end{tabular}




\subsection{Visualization of Most Popular Keywords, Source Pattern and Documents based Citations}

Keywords are terminologies which are mentioned in a scientific publication to highlight the important elements of the paper and to make it easy to search. (Mahala \& Singh, 2021) The Figure IV, has used the VOSviewer map to depict the most frequently used keywords within the Title of the research article in the area of gender equality. It can be observed that the size of the circle is proportionate to how frequently a specific keyword is used in the study of gender equality. The various colour patches represent the different clusters of most used keywords in the publications related to the study area. There are multiple clusters of keywords plotted on the Figure IV, out of which there are 15 most frequently used, they are, Gender Equality, Human, Women, Human Rights, Empowerment, Women Status, Gender Disparity, Sex Difference, Psychology, Gender Identity, Women's Rights, Women's Health, Domestic Violence, Poverty and Public Health. The width of the lines of network reflects the intrarelationship among the keywords, i.e., the thicker the network line, stronger the association.

\section{Figure IV}

\section{Visualization of Keyword matching within Title}

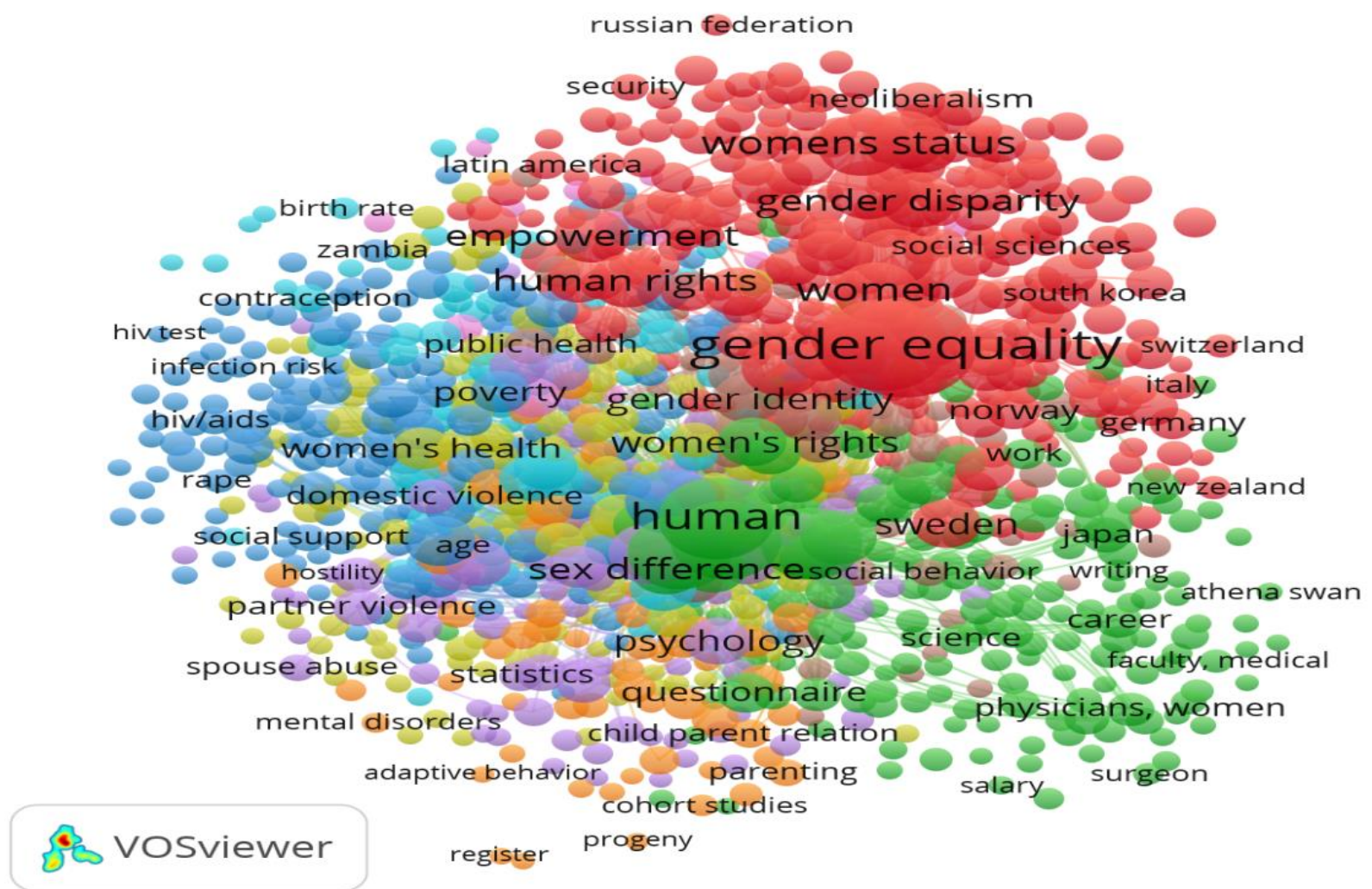


Figure V shows the multiple clusters of source plotted in the Figure, it is observed that gender and development, gender work and organisation, politics and gender, and social politics are the most frequently used source title in the study.

\section{Figure V}

\section{Visualization of Citation based on Source Title Pattern}

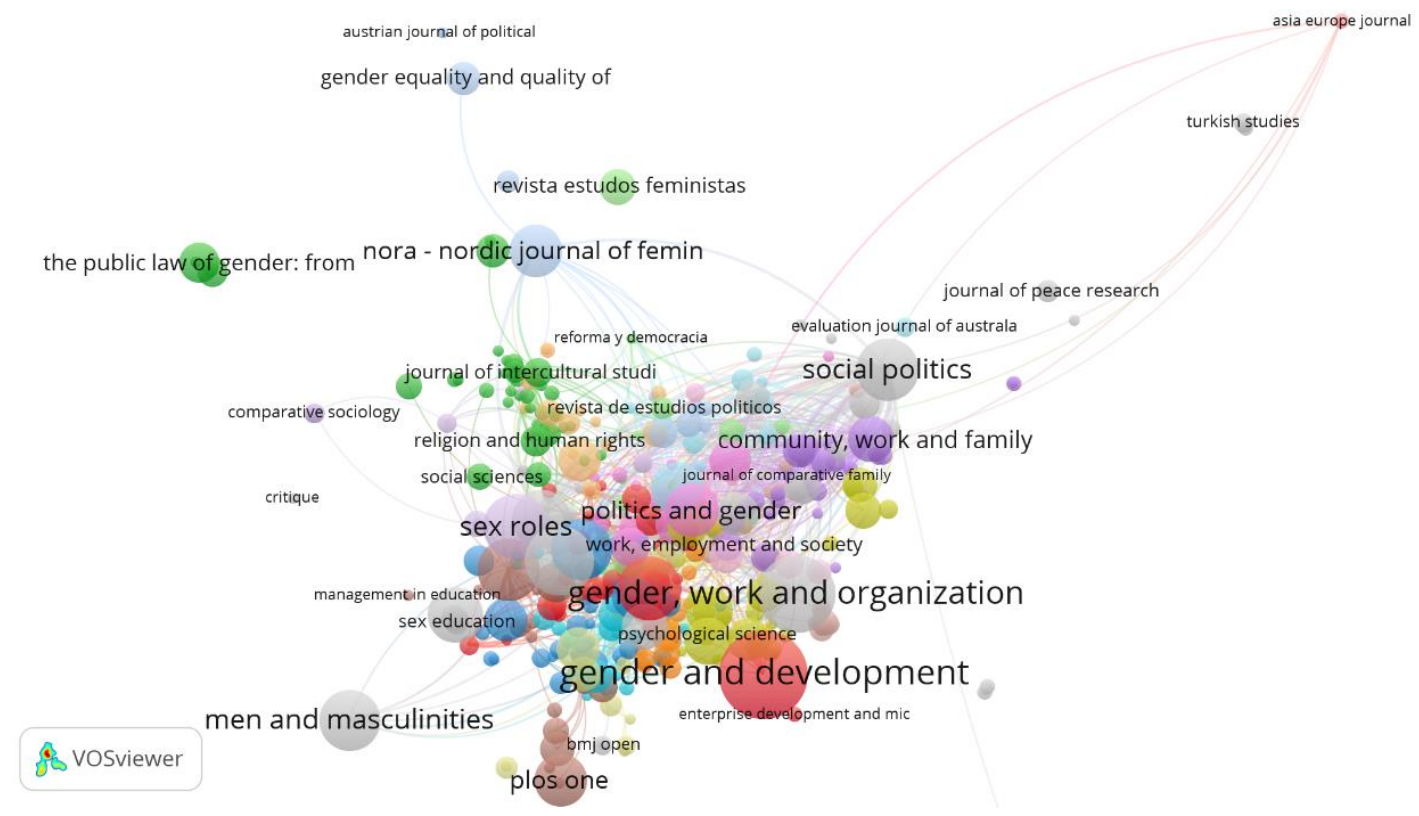

Figure VI shows the multiple clusters of documents plotted in the Figure, it is observed that Connel R, Armstrong E., Cotter D. and Krook M are the most frequently used in the study.

Figure VI

\section{Visualization of Document based Citations}

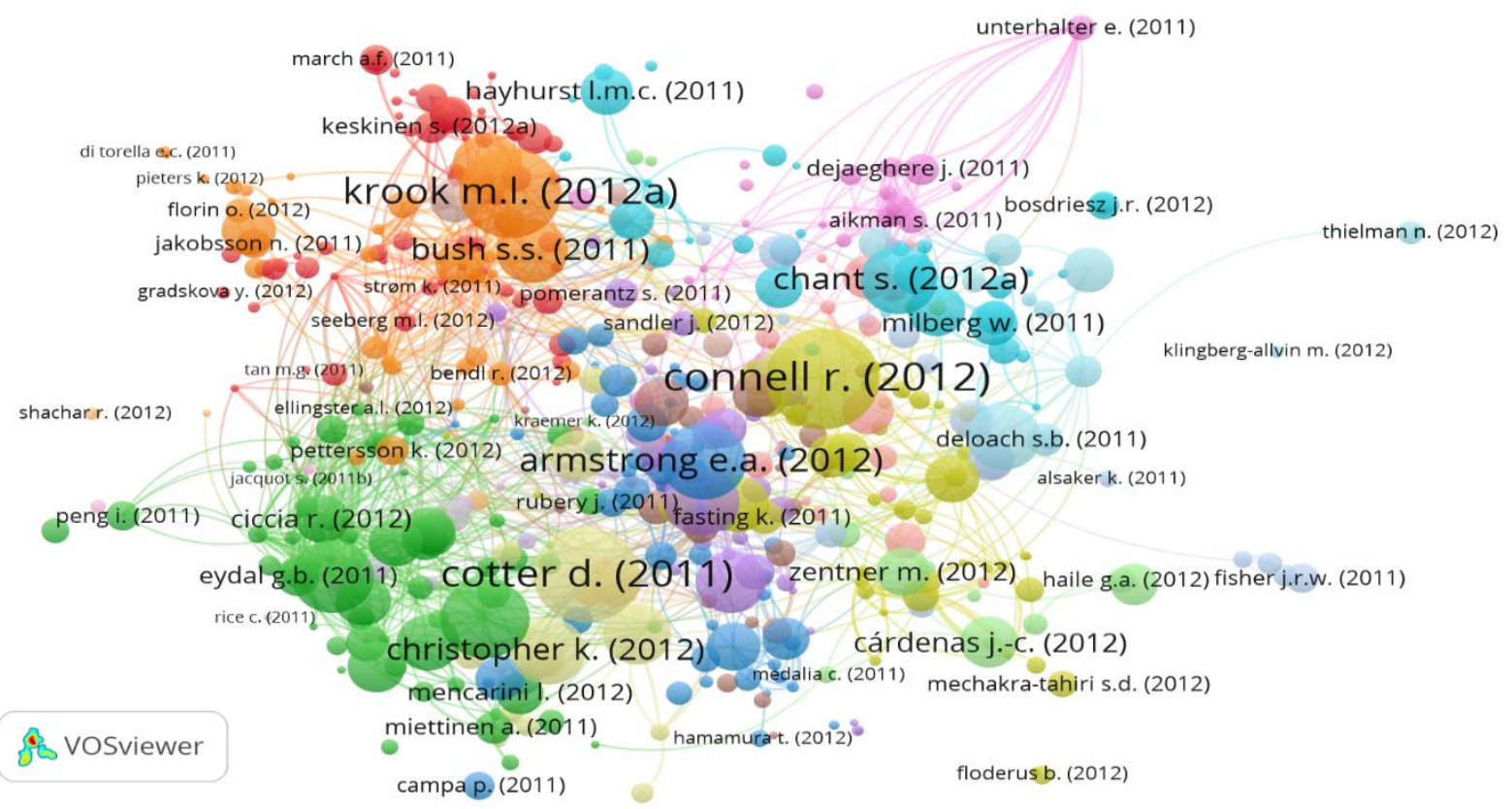




\subsection{Visualization of International Collaborations in Research Output}

Research collaboration among various nations, is one of the most important parameters to evaluate the reach and impact of the scientific productions. (Mahala \& Singh, 2021) The Figure VII, indicates the collaborating nations' network of scientific productions in the domain of gender equality through VOSviewer. These illustrates research collaboration among 35 countries. The width of the line of network indicates the collaborative strength. The various clusters of collaboration are marked by the different colour patches. In the Figure V, eight countries (USA, UK, Sweden, Spain, Australia, Canada, Srilanka and Netherlands) from eight different clusters (colour patches) have undertaken the major collaborative work. Among them four countries (UK, Sweden, Spain and Netherlands) are located in Europe, two (USA and Canada) in North America, one (Srilanka) in Asia and one (Australia) in Oceania. The size of the circle indicating a specific country, represents the contribution of that country in the overall collaborative work. Figure VIII reflect the co-citation of cited references.

Figure VII

\section{Visualization of country-wise Co-Authorship pattern}

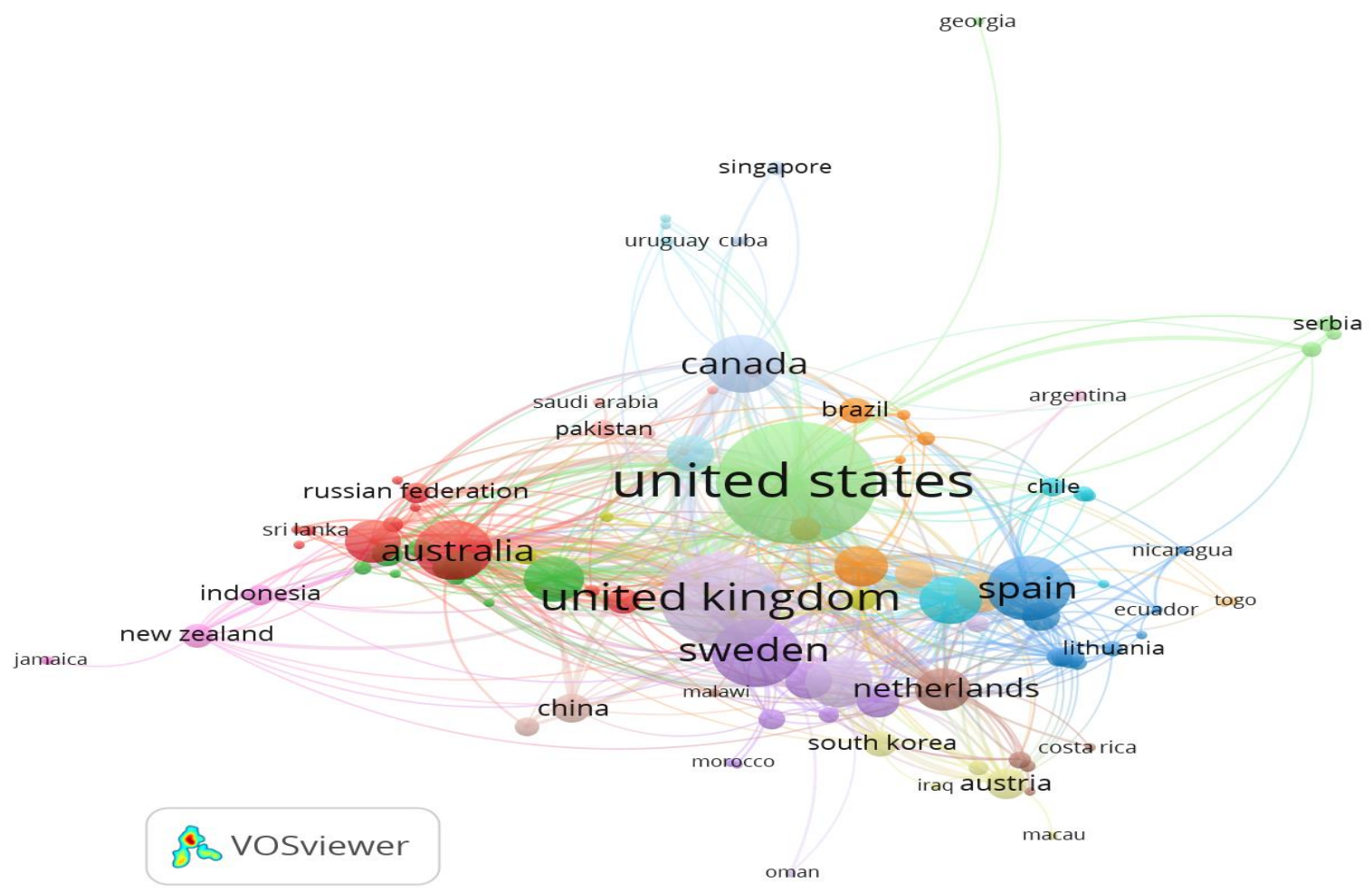




\section{Figure VIII \\ Visualization of Co-citation pattern}

is VOSviewer

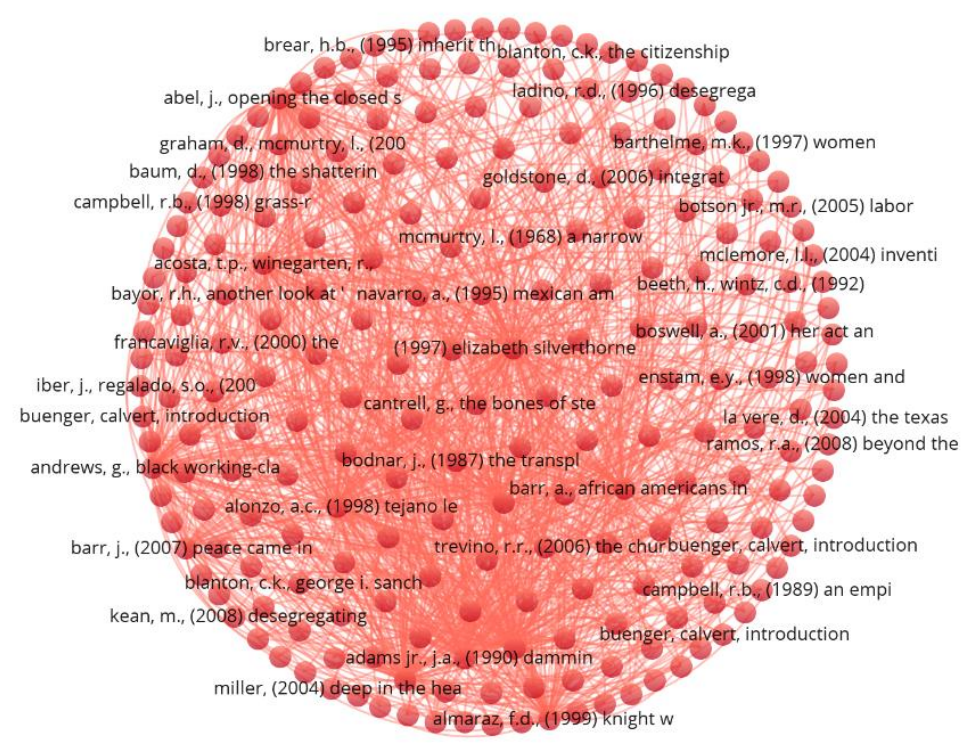

\subsection{Visualization of Top Productive Institutions in Research outputs}

Figure IX points out the most productive Institutions in terms of number of published articles in the field of gender equality. It can be seen that Ume University is the most productive institution with 132 published articles. It is followed by University of California (103), Stockholm University (81), University of Oxford (67), University of Oslo (65), University of Gothenburg (60), University of Helsinki (58), University of Toronto (55), University of London (53), Uppsala University (51). It has been observed that among the top ten productive Institutions, the first three (Ume University, University of California and Stockholm University) accounts for nearly half (44\%) of the publications.

\section{Figure IX}

\section{Distribution of Most Productive Institutions}

\begin{tabular}{|c|c|c|}
\hline \multicolumn{3}{|c|}{ Most Productive Universities/Institutionas } \\
\hline \multirow{10}{*}{ 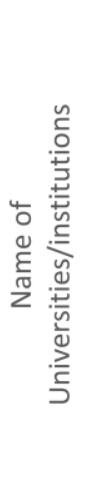 } & Ume University & 132 \\
\hline & University of California & 103 \\
\hline & Stockholm University & 81 \\
\hline & University of Oxford & 67 \\
\hline & University of Oslo & 65 \\
\hline & University of Gothenburg & 60 \\
\hline & University of Helsinki & 58 \\
\hline & University of Toronto & 55 \\
\hline & University of London & 53 \\
\hline & Uppsala University & 51 \\
\hline
\end{tabular}




\subsection{Visualization of Bibliographic Coupling of Institutions}

Figure X and XI depicts the bibliographic coupling of Institutions and Visualization of Bibliographic Coupling of Institutions respectively by using the VOSviewer. In the overlay visualization, each Institute has cited another Institute for more than two time. As per this parameter, nine Institutions were identified. The width of the line of network indicates the strength of the bibliographic coupling. The various clusters of Institutions are marked by the different colour patches. In the Figure, the Institutions with the highest total link strength has been illustrated. Thus, the size of the circle indicating a specific Institution, represents that that Institution has received greatest numbers of citations in the overall scheme of bibliographic coupling. Here, it can be seen that the top Institution with a difference is University of Helsinki (Finland), followed by University of Oxford (UK). The other notable Institutions were Stockholm University (Sweden), University of Oslo (Norway), University of British Columbia (UK), etc. This shows that the bibliometric coupling is highest among the European Nations.

\section{Figure $\mathrm{X}$}

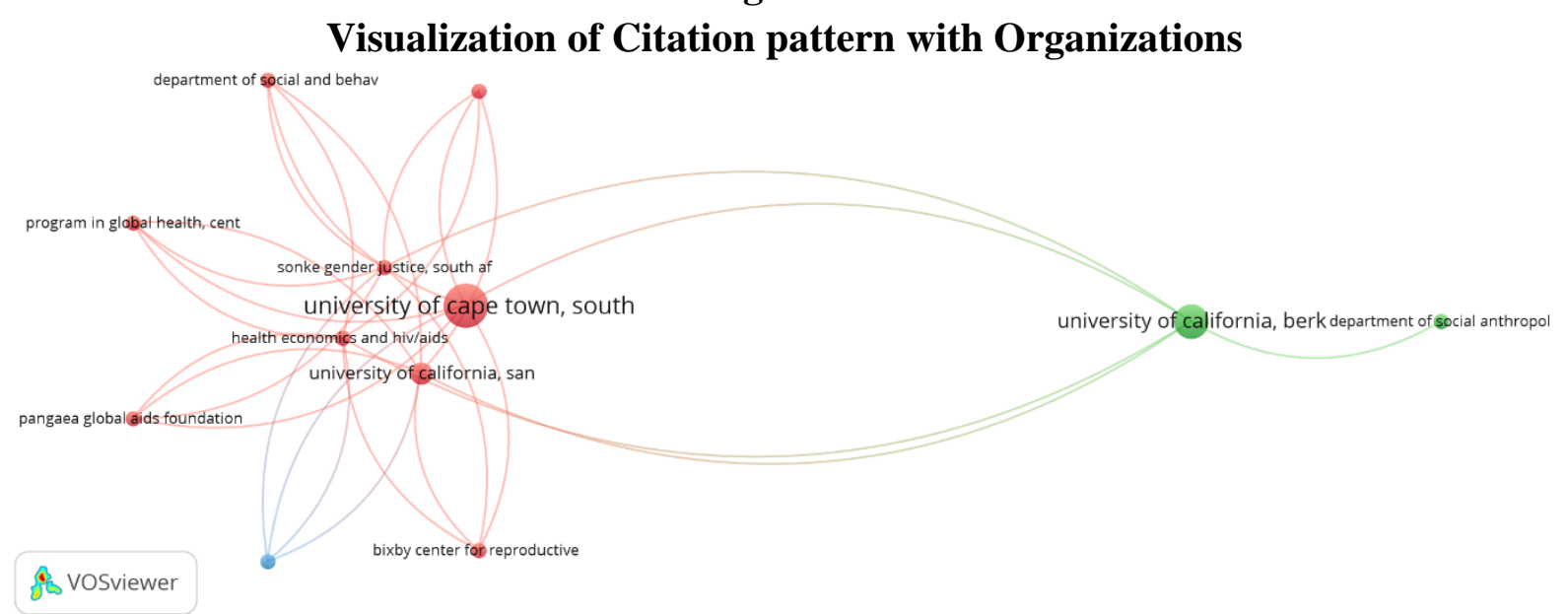

Figure XI

Visualization of Bibliographic Coupling of Institutions

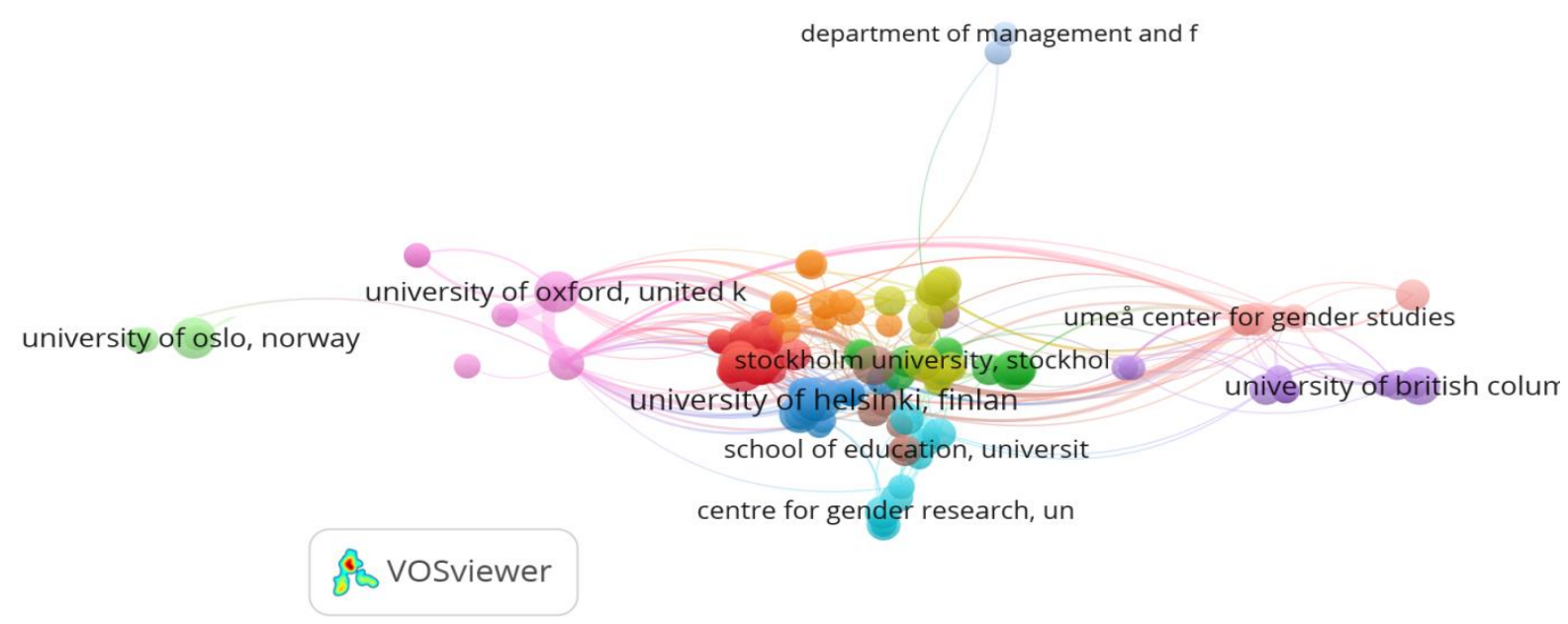




\section{Conclusion}

Bibliometrics - a form of statistical application, has the potential to conduct quantitative analysis of the scientific articles related to certain specific topic using mathematical tools and techniques. Various research areas are increasingly using the bibliometric methodology to understand the impact of their domain, the influence of a set of authors, the impact of a specific article, or to search some high impact articles within a particular area of scientific work. (Wang, et al., 2020)

In the present study, the bibliometric method has been used to explore scientific productions related to the field of gender equality from 2011 to 2020 , and it proved to be a useful method to analytically study the growth of scientific work in this field. The empirical data for the present study was collected from the Scopus database. 7619 scientific productions related to gender equality were found for the study duration.

The study analysed the quantitative features of the identified scientific productions related to the topic. Though only the Scopus database was used to collect the empirical data, the findings can be said to be representative. At the same time, it can be said, that the study findings have the potential to furnish meaningful information regarding the enormity of gender-based research, while providing direction to upcoming research in the field. At the same time, this study may act as an instance of how the librarians and scholars from the domain of gender studies and broader social science fraternity can use bibliometrics to identify articles related to a specific topic. By exploring the trends in research activity, most prolific authors, authors' productive life, most productive institutions and their respective countries, researchers can apply bibliometrics to identify the relevant resources to apply when researching a specific topic.

This study also has immense practical implications. It has been observed that though many bibliometric studies have been conducted in the domain of natural and life sciences, but very limited studies have been conducted in the broader field of social sciences. Thus, this study will provide valuable insight into the application of tools of bibliometric analysis for studying various aspects of social sciences, with a special emphasis on gender equality.

As present study has covered the bibliometrics analysis of gender equality of last 10 years of research published and available under Scopus Database, Further study can carry out with wide scope of research published in Scopus, Web of Science (WS) and Google Scholars (GS) which may provide more clear scenario on this domain. 


\section{References}

Aria, M. \& Cuccurullo, C. (2017) bibliometrix: An R-tool for comprehensive science mapping analysis, Journal of Informetrics, 11(4), pp 959-975.

Balutagi, S., Huded, S. M., \& Devi, K. N. (2020). Measuring Research Contributions of Prof. Anurag Kumar: A Scientometric Analysis. Library Philosophy and Practice (e-journal), 4208. Retrieved from https://digitalcommons.unl.edu/libphilprac/4208

Barnett, M. (2018). Gender Equality, Norms and Practices: Post-script to Special Issue on New Actors, Old Donors and Gender Equality Norms in International Development Cooperation. Progress in Development Studies, 18(3), 208-213. doi:10.1177/1464993418766588

Chary, S. N. (2016). Gender Equality: A View From India. Journal of Management Inquiry, 26(1), 108-111. doi:2075/10.1177/1056492616664853

Chaudhari, S., Chaudhary, A. S., \& Vaishnav, N. (2017). Bibliometric Analysis of Book of Papers of Annual Seminars of Ahmedabad Library Network (ADINET).

Chaudhari, S. P., Bhatt, A., \& Mandalia, S. H. (2020). Trends in Annual Seminar Papers of Ahmedabad Library Network: A Bibliometric Analysis. Library Philosophy and Practice (ejournal), 4281. Retrieved from https://digitalcommons.unl.edu/libphilprac/4281

Das, Suman (2021). "Research Trends of E-Learning: A Bibliometric and Visualisation Analysis". Library Philosophy and Practice (e-journal). 5257. https://digitalcommons.unl.edu/libphilprac/5257

Haq, Ikram Ul; Rehman, Shafiq ur; Al-Kadri, Hanan; and Iqbal, Abid, (2021). "Bibliometric Evaluation of the Scopus Indexed Scholarly Literature of Ministry of National Guard - Health Affairs, Saudi Arabia". Library Philosophy and Practice (e-journal). 5261. https://digitalcommons.unl.edu/libphilprac/5261

Jones, A. W. (2016). Forensic Journals: Bibliometrics and Journal Impact Factors. In J. P. James, \& R. W. Byard (Eds.), Encyclopedia of Forensic and Legal Medicine (Second ed., pp. 528-538). Elsevier Ltd. doi:https://doi.org/10.1016/B978-0-12-800034-2.00181-6

Kataria, A., Kumar, S., \& Pandey, N. (2020). Twenty-five years of Gender, Work and Organization: A Bibliometric Analysis. Gender, Work \& Organization, 28(4). doi: https://doi.org/10.1111/gwao.12530

Kolle, S. R. (2017). Global Research on Information Literacy: A Bibliometric Analysis from 2005 to 2014. The Electronic Liberary, 35(2), 283-298. doi:10.1108/EL-08-2015-0160

Kurzman, C., Dong, W., Gorman, B., Hwang, K., Ryberg, R., \& Zaidi, B. (2019). Women's Assessments of Gender Equality. Socius: Sociological Research for a Dynamic World, 5, 113. doi:0.1177/2378023119872387

Laila, Nisful; Rusydiana, Aam Slamet; and Assalafiyah, Aisyah,(2021). "The Impact of Covid-19 on The Halal Economy: A Bibliometric Approach" . Library Philosophy and Practice (e-journal). 5417. https://digitalcommons.unl.edu/libphilprac/5417

Mahala, A., \& Singh, R. (2021, April 9). Research Output of Indian Universities in Sciences (20152019): A Scientometric Analysis. Library Hi Tech, Ahead of Print(Ahmead of Print). Retrieved from 10.1108/LHT-09-2020-0224 
Miotto, G., Lopez, M. P., \& Rodriguez, J. R. (2019). Gender Equality and UN Sustainable Development Goals: Priorities and Correlations in the Top Business Schools' Communication and Legitimation Strategies. Sustainability, 1-18. doi:10.3390/su11020302

OECD. (2010). Gender Equality and Pro-Poor Growth. OECD. Retrieved from https://www.oecd.org/dac/gender-development/47566333.pdf

OECD. (2015). Gender Equality and Women's Rights in the Post-2015 Agenda: A Foundation for Suatainable Development. OECD. OECD. Retrieved from https://www.oecd.org/dac/genderdevelopment/POST-2015\%20Gender.pdf

OHCHR. (2021). Women's Human Rights and Gender Equality. Retrieved 329,2021 , from United Nations Human Rights Office of The High Commissioner: https://www.ohchr.org/EN/Issues/Women/Pages/WomenAndGenderEquality.aspx

Palmieri, S. (2013). Sympathetic Advocates: Male Parliamentarians Sharing Responsibilty for Gender Equality. Gender \& Development, 21(1), 67-80. doi:https://ezproxy.tiss.edu:2075/10.1080/13552074.2013.767501

Palomo, J., Domecq, C. F., \& Laguna, P. (2017). Women, peace and security state-of-art: A biblopmetric analysis in social sciences based on SCOPUS database. Scientometrics, 113, 123-148. doi:https://doi.org/10.1007/s11192-017-2484-x

Patel, P., \& Bhatt, A. (2019). Quantitative Synthesis of Published Research: A Study of Gujarat University. Library Philosophy and Practice (e-journal), 2514. Retrieved from https://digitalcommons.unl.edu/libphilprac/2514

Patel, V. (2014). Gender Equality and Human Rights. School of Development Studies, SNDT University, Advanced Centre for Women's Studies. Mumbai: SNDT University. Retrieved from https://papers.ssrn.com/sol3/papers.cfm?abstract_id=3182315

Patyal, V., Jaspal, D., \& Khare, K. (2020, June 16). Wastewater Treatment Technologies: A Bibliometric Analysis. Science \& Technology Libraries, 39(4), 383-394. doi:https://doi.org/10.1080/0194262X.2020.1775164

Peace Corps. (2021). Global Issues: Gender Equality and Womwn's Empowerment. Retrieved March 29, 2021, from Peace Corps: https://www.peacecorps.gov/educators/resources/global-issuesgender-equality-and-womens-empowerment/

Saravanan, G., \& Dominic, J. (2014). A Ten-year Bibliometric Analysis of Research Trends in Three Leading Ecology Journals during 2003-2012. Journal of Information Science Theory and Practice, 2(3), 40-54. https://doi.org/10.1633/JISTAP.2014.2.3.4

Schwab, K., Smans, R., Zahidi, S., Leopold, T. A., Ratcheva, V., Haussman, R., \& Tyson, L. D. (2017). Insight Report: The Global Gender Gap Report 2017. Cologny/Geneva, Switzerland: World Economic Forum.

Scopus. (2021, April). Retrieved from Scopus: https://www.scopus.com/

Singh, S., \& Pandita, R. (2018). Measurement of Global Nursing Research Output: A

Bibliometric Study (1996-2015). Journal of Information Science Theory and Practice, 6(1), 31-44. https://doi.org/10.1633/JISTAP.2018.6.1.3

Slavinski, T., Todorovic, M., Vukmirovic, V., \& Montenegro, A. M. (2020, December 28). Women, Entrepreneurship and Education: Descriptive Bibliometric Analysis Based on SCOPUS Database. Women's Entrepreneurship and Education, 3(4), 181-201. doi:https://doi.org/10.28934/jwee20.34.pp181-201 
Steel, G., \& Kabashima, I. (2008). Cross-regional Support for Gender Equality. International Political Science Review, 29(2), 133-156. doi:10.1177/0192512107085609

Torgrimson, B. N., \& Minson, C. T. (2005). Sex and Gender: What is the Difference? Journal of Applied Physiology, 99, 785-787. doi:https://doi.org/10.1152/japplphysiol.00376.2005

UN. (2015). United Nation Sustainable Development - Goal 5 Gender Equality. Retrieved 329, 2021, from United Nations: https://www.un.org/sustainabledevelopment/gender-equality/

UN Women. (2017). SDG 5: Achieve Gender Equality and Empower all Women and Girls. Retrieved 3 29, 2021, from https://www.unwomen.org/en/news/in-focus/women-and-the-sdgs/sdg-5gender-equality

UN Women. (2021). The Beijing Platform for Action Turns 20. Retrieved April 13, 2021, from UN Women - United Nations Entity for Gender Equality and the Empowerment of Women: https://beijing20.unwomen.org/en/about

Victoria, P (2021). "Research Output on ICT during the Period 2016-2020: A Scientometric Analysis" (2021). Library Philosophy and Practice (e-journal). 5398. https://digitalcommons.unl.edu/libphilprac/5398

Wang, C., Xia, X., Li, G., Zhi, G., Wu, Y., Wang, L., \& Ruan, L. (2020). Research Progress on CRISPR/Cas9: A Bibliometric Analysis Based on a SCI-Expanded Database. Serials Review, 46(4), 264-274. doi:10.1080/00987913.2020.1851440

WHO. (2002). Gender Definitions. Retrieved March 29, 2021, from World Health Organization Regional Office for Europe: https://www.euro.who.int/en/health-topics/healthdeterminants/gender/gender-definitions 